\title{
The characters of the traditional residence of Sasak tribe based on sikut awak: An ethnomathematics study
}

\author{
Lalu Muhammad Fauzi *, Muhammad Gazali \\ Mathematics Education Department, Universitas Hamzanwadi, West Nusa Tenggara, Indonesia \\ *Correspondence: Imfauzi@ hamzanwadi.ac.id
}

(C) The Author(s) 2022

\begin{abstract}
In cultural anthropology, people have recognized various mathematical activities, such as counting, calculating, measuring, and weighting, with different terms derived from each culture. Community activities in responding to the existence of their environment will give rise to mathematics as part of problem-solving, including finding characters or features of residence to build. Therefore, this study explores mathematical forms in the measurement of residential characters based on sikut awak that can be used in mathematics learning. This research is an ethnographic study. Data were collected from various literature studies, field observations, and interviews. Informants included in the study were two cultural experts, one Adat leader, and one traditional builder who knows sikut awak's measurement format in determining the traditional residential characters of Sasak people. This study shows that the determination of residential characters uses mathematical models in its calculation.
\end{abstract}

Keywords: ethnomathematics; Sasak culture; residential characters; sikut awak 


\section{Introduction}

Humans develop mathematics by techniques or means in responding to the environment to find explanation, comprehension, experience, and solutions toward problems or phenomena at hand (D'Ambrosio, 2007; Freudenthal, 2002). Along with his followers, Aristoteles perceived that mathematics originates from humans' life issues (Anglin, 1994). Social constructivism views mathematics as a social construct. This view refers to the nature of traditions that accept that human language, rule, and agreement hold a crucial role in developing and validating mathematical truth (Ernest, 1991). Mathematics is not culture-free because it is affected by social, historical, environmental, and geographical aspects where the human life process grows (D'Ambrusio, 2016). however, in reality, people conceive a narrow comprehension of mathematics. Mathematics is considered as a formal knowledge found and acquired from schools. Teachers have yet to integrate students' new knowledge from their environment. Thus, mathematics is considered a rigid formal routine. As a result of the whole situation, mathematics is perceived as a learning subject that is associated with formulas, calculations, numbers and is a difficult subject.

The gap between mathematics and culture is a phenomenon occurring in the community. Therefore, ethnomathematics emerges as a means to learn mathematics in the cultural aspect. Ethnomathematics is a means to study and link ideas or notions that have been used and developed by people or members of different cultures (D'Ambrusio, 2016). The concept of tradition is not characterized by a set of static forms but by different production processes and cultural transmissions (Zhang, 2019). Ethnomathematics attempts to adjust or alter mathematics' position to root on culture, accommodating diverse ideas so that students will think critically, democratically, and tolerably (D'Ambrusio, 2016; Kirchgräber, 2001). Ethnomathematics is a pedagogical innovation in mathematics learning aimed at students to love mathematics, be motivated, and improve their creativity in learning mathematics (Prahmana et al., 2021). Thus, ethnomathematics is a learning innovation that roots in culture by linking mathematical ideas to grow within the community so students can easily learn mathematics.

Sasak people with their diverse culture store a lot of mathematical ideas in various cultural activities. One of which is the tradition before starting to build a residence. Bale (houses) in Sasak's term is a micro space in the residential spatial system of Sasak people. Similar to macro and meso spaces, micro space also has a similar system entity and cosmic structure (Fatrurrahman, 2016). Similar to macro and meso spaces, micro space also has a similar system entity and cosmic structure (Fatrurrahman, 2016). House is a living place or space where individuals spend most of their time and life, and the house represents what is felt by the residents through the environment where they live (Ruff \& Olson, 2009). In the western perspective, the residence is generally understood as a limited and static physical entity (Ching, 2007). At the same time, residence, as in the cultural tradition of a community, is illustrated as the spirit that defines human habitat socio-culturally (Markevičienè, 2012).

House as an artificial space represents its owner as of the cosmic subject; therefore, a house is built to provide comfort and safety for the owner. Combining architectural elements 
became very influential to human psychology and sense perception (Kimberly Mah, 2013). Factors are affecting the nature of residence and the life quality of the resident, one of which is residential space arrangement (Faturrahman, 2016). The importance of residential space arrangement is reflecting characteristics of the area and the values and culture of the people in which the residential space arrangement reflects characteristics of its people (Ghaffarianhoseini et al., 2014). In this context, house owners have to harmonize the existence of their house with both physical and non-physical environments (tangible or intangible) (Fatrurrahman, 2016). According to the observation results, the form, layout, and architecture of traditional residence of Sasak people are affected by: (a) characters and location; (b) time of establishment; (c) village spatial pattern; and (d) community's character.

Many researchers studied the uniqueness of the Sasak tribe's culture from various perspectives, including the research conducted by Alkhusairi (2016) that studied the historical places in Lombok Island, which focused on developing a mathematics learning model that is based on Sasak culture. This study found a learning model or format by utilizing historical places as the ethnomathematics-based mathematics learning. Sabilirrosad (2014) research studied the woven fabric that exists in Pringgasela with ethnomathematics research focus on Sasak's weaving in the learning of geometric concepts, such as points, lines, and figures as well as geometric transformations, especially on translation and dilatation. The research conducted by Supriyati (2019) studied Sasak's cultural values in ethnomathematics perspective, which studied the illustration that cultural values can be implemented in mathematics learning by modeling various cultural activities implemented by Sasak people. Most of the studies presented above-identified Sasak's cultural artifacts and educational values mentioned in Sasak's cultural values. This study has a different analysis from the studies aforementioned above, namely finding the mathematical forms in characters or features of the residence to build. Therefore, this study aims to explore mathematical forms in the measurement of residential characters based on sikut awak, which can be used in mathematics learning.

\section{Methods}

The method used in this study was ethnographic as the activity to describe culture, which aims to understand the way of life of others from the actual perspective (Spradley, 2016). The selection of this ethnographic method is in line with ethnomathematics' purpose, namely learning ideas, methods, and techniques in a particular culture from the perspective of cultural members (Ascher \& D'Ambrosio, 2012). Data were collected through a field study. Interviews were conducted with Mr. Lalu Agus Fathurrahman as a 69 years-old expert of Sasak culture; Mr. Raden Gedarip as a 70 years-old expert of Bayan Culture, Amaq Riajim as a 65 years-old Adat leader, and Amaq Darsih as an 80 years-old traditional builder.

Cultural theories are always implied in ethnographic studies because the community often uses the meaning system to manage their behavior, understand themselves, and understand their place (Spradley, 2016). This method is consistent with ethnomathematics studies because ethnomathematics is the mathematics used and developed by a group of cultures (U D'Ambrosio, 2007). This argument is in line with the aim of this research, namely discovering 
mathematical ideas developed in determining the residential characters of Sasak people based on sikut awak (human body size).

The collected data were analyzed through content and taxonomy analyses. These analyses were applied to discover the idea and meaning and the mathematical calculation applied in determining residential characters based on the owner's sikut awak.

\section{Results}

Before starting new house construction, Sasak people begin the process through a ritual called bangar, namely a ritual to clean the land from negative energy and harmonize the positive energy of nature with the land as the site for the new residence. This activity is often committed by lokaq mangku or belian bale. The bangar concept in cosmologic thought of Sasak is the harmonization of the relationship among humans, nature, and God. The aim is for the newly-built residence to be free from the disturbance of spirits or bad intentions of others so the resident will feel peaceful to live in it. This thought is consistent with the concept that space has an energy field that needs to be synchronized, and its circulation should be managed to prevent collisions (Fatrurrahman, 2016).

The general construction of traditional and modern buildings highly prioritizes the security aspect. In the construction process of traditional residence, Sasak people follow many instructions from the builder, either from the selection of building materials or the construction time. In the process, traditional builders of Sasak people always work with precision ( creativity (tuhu). While in the cosmologic context, kemaliq (a forbidden matter) provides limitations on attitude and behavior to be more careful in doing activities. Kemaliq becomes the place to reflect, finding normative values to embrace daily.

According to the interview with Lalu Agus Fathurrahman, it was revealed that in the cosmology of the traditional residence of Sasak people, there is a feature known as sikut (size). However, the size in this context does not only relate to width, length, and height but also relates to space (sikut rong), time (sikut waktu), and materials (sikut ramon). Sikut's length is oriented towards the lauq (south) - daya (north) direction, while width oriented towards julu (front) - mudi (back) direction. Sikut's height is related to the trait or character of the residence determined by sikut awak (body size), especially the owner's depa size. Sikut waktu is related to when the building construction starts, sikut rong (space) is related to the residence's layout. Sikut andang refers to the orientation of gubuk's layout, which is related to the accessibility of the house to be built with the neighboring houses. In Sasak's tradition, the implementation of sikut andang during the start of house construction refers to the edar nage system in Sasak's warige. The residential size of Sasak people uses a comparison pattern, as seen in Figure 1 and Table 1 as follows. 


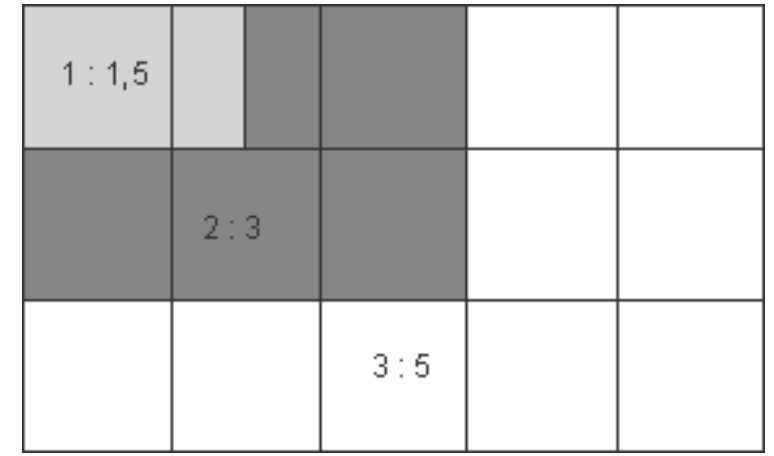

Figure 1. The comparison of Sasak people's residence

Table 1. The sizes of Sasak people's residence

\begin{tabular}{cc}
\hline Size comparison & Estimation \\
\hline $1: 1.5$ & $5 \times 7.5$ sikut \\
$2: 3$ & $7 \times 10.5$ sikut \\
$3: 5$ & $9 \times 15$ sikut \\
\hline
\end{tabular}

The size in the traditional carpentry system of Sasak applies Sasak's anthropometric system, namely the size referring to the human's body size, called as sikut awak in Sasak's term. The sikut awak that being used is nyari (the width of an adult's fingers), kepel (the size of an adult's fist), jengkak (the size of an adult's hand span), hasta (adult's cubit), depa (the size of an adult's head), and perujung (the height from toe to toe of an adult). In addition, there is a self-made wooden tool such as penjangka (angle measuring tool) as presented in Figure 2 as follows.

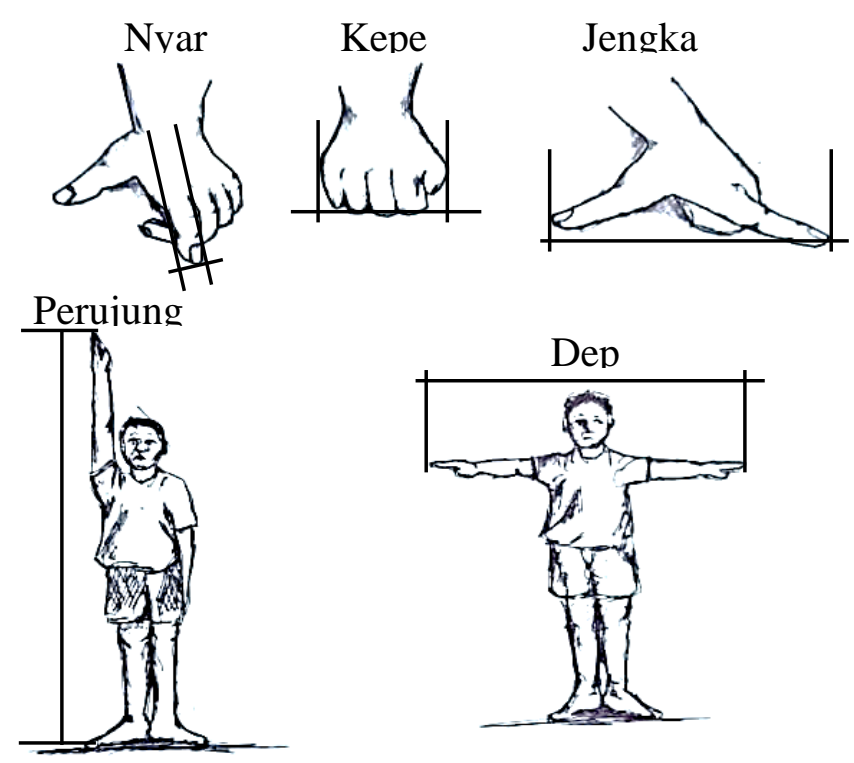

Figure 2. Sasak’s anthropometric Sizes (Fathurrahman, 2016) 
Next, the size of Sasak's anthropometry can be estimated with the length as seen in Table 2 as follows.

Table 2. Sasak's Anthropometric Sizes

\begin{tabular}{cc}
\hline Sizes & Estimation $(\mathbf{c m})$ \\
\hline Nyari & 1.5 \\
Kepel & 10 \\
Jengkal & 20 \\
Hasta & 50 \\
Depa & 150 \\
Perujung & 200 \\
\hline
\end{tabular}

Sikut waktu is related to the time when the house is built. The primary reference is engkal pekan (the characters of time in a week symbolized by natural elements) in warige system or Sasak's calendar. Aura of a residence is affected by selecting wood materials (sikut ramon). Ramon (wood) that is being used can survive any season and weather.

The implementation of anthropometry on the frame height or the residence wall of Sasak people refers to warige system or Tajul Muluk book. In measuring the house height that will be built, the builders use Sasak's anthropometry by measuring the owner's height (female owner). The implementation of anthropometry in the structure of Sasak people is on the frame height or house wall. The implementation of anthropometry on the frame height of house wall is related to the character of house to be built. For this matter, Sasak people are referring to Sasak's warige system or Tajul Muluk book.

The rules and measurement of traditional residence's height of Sasak people are based on the owner's depa length (Fatrurrahman, 2016)

1. The owner's depa size

The depa size is divided by 3 , then the one third is divided by 10

Note

3 = showing that the human life process consists of three stages, namely the womb, the world, and the afterlife

$10=$ the number of characters or natures of Sasak people's traditional residence

2. The measurement results are used as the means to measure the height of wall based on the names of house and based on the beliefs of Sasak people.

The characters or features of residence in the tradition of Sasak people can be seen in Table 3 as follows.

Table 3. Characters or features of Sasak people's residence

\begin{tabular}{cll}
\hline No & Character or Feature & \multicolumn{1}{c}{ Meaning } \\
\hline 1 & Ketangkil & $\begin{array}{l}\text { Providing happiness and always } \\
\text { full with people }\end{array}$ \\
\hline 2 & Asap & Sorrow-bringing \\
\hline 3 & Singa & $\begin{array}{l}\text { Free from danger, the resident will } \\
\text { become a religious leader }\end{array}$ \\
\hline 4 & Anjing & $\begin{array}{l}\text { Often get into conflicts and bad- } \\
\text { tempered }\end{array}$ \\
\hline 5 & Kuda & $\begin{array}{l}\text { Goodness, heading towards } \\
\text { perfection }\end{array}$ \\
\hline 6 & Kakatua & Assets can't never last \\
\hline
\end{tabular}




\begin{tabular}{cll}
\hline No & Character or Feature & \multicolumn{1}{c}{ Meaning } \\
\hline 7 & Harimau & Benevolence and blessed \\
\hline 8 & Naga & Good and peaceful \\
\hline 9 & Dacin & Fickle/inconsistent \\
\hline 10 & Ular & $\begin{array}{l}\text { Benevolence, respected, lots of } \\
\text { relatives }\end{array}$ \\
\hline
\end{tabular}

A person who wants to build a residence based on the beliefs of Sasak people should ask about the character of the house that will be built based on sikut awak (body size) of the female owner to the belian bale (house shaman) to be measured and to define the character of the house that will be built. The measurement is conducted as follows.

1. For example, the owner's depa length is $165 \mathrm{~cm}$

The owner's depa length is divided by 3

$\frac{165}{3}=55$

Next, the result is divided by 10

$\frac{55}{10}=5,5$ remaining

The remainder of the division is the character of the residence that will be built.

$5(K u d a)$ means that the house that will be built has the character of goodness and heading towards perfection.

2. For example, the owner's depa length is $183 \mathrm{~cm}$

The owner's depa length is divided by 3

$\frac{186}{3}=62$

Next, the result is divided by 10

$\frac{62}{10}=6,2$ remaining

The remainder of the division is the character of the residence to be built

2 (Asap) means that the house that will be built has the character of sorrow-bringing

The results of the calculations above can be written in the form of modulo arithmetic. The commonly used notation is a mod $m=r$ (reads "a modulo $\mathrm{m} "$ ), which shows that $r$ is the remainder acquired if $a$ is divided with $m$. If $a$ is an integer and $m$ is an integer greater than 0 , then:

1. $55: 10=5,5$ remaining, which reads $55 \bmod 10=5$

2. $50: 10=5,0$ remaining, which reads $50 \bmod 10=0$

3. $62: 10=6,2$ remaining, which reads $62 \bmod 10=2$

From the calculation result done by belian bale, not every residential character found about sikut awak has a good nature. Sometimes, the owner's depa size is not possible to be made as the reference for the house's height. Therefore, to anticipate this issue, belian bale uses the standard house height according to the belief of Sasak people, namely $200 \mathrm{~cm}$. Table 4 shows more details about this selection. 
Table 4. The Selection of residential characters

\begin{tabular}{clc}
\hline No & \multicolumn{1}{c}{ Character } & Calculation \\
\hline 1 & Ketangkil & $200+5$ \\
2 & Asap & $200+10$ \\
3 & Singa & $200+15$ \\
4 & Anjing & $200+20$ \\
5 & Kuda & $200+25$ \\
6 & Kakatua & $200-5$ \\
7 & Harimau & $200-10$ \\
8 & Naga & $200-15$ \\
9 & Dacin & $200-20$ \\
10 & Ular & $200-25$ \\
\hline
\end{tabular}

Based on the calculation shown above, it is indicated that the standard height of a house is seperujung of the female owner, namely $200 \mathrm{~cm}$. Residential characters can be determined by adding and subtracting. The mathematical patterns are presented in the form of arithmetic progressions, namely:

1. For characters no $1-5$

$$
\begin{aligned}
& 200+205+210+\ldots \\
& a=200 \\
& b=5
\end{aligned}
$$

2. For characters no $6-10$

$200+195+190+\ldots$

$\mathrm{a}=200$

$\mathrm{b}=-5$

\section{Discussion}

The results of mathematical exploration on the finding of residential characters based on sikut awak according to the belief of Sasak people can enhance references and knowledge in which cultural context can be made as to the initial step in mathematics learning-designing mathematics experience for meaningful learning following students' initial knowledge acquired from their environment. For that, teachers must facilitate the cultural diversity of students on key elements during the designing of mathematics learning activities (Burton, 2010). Students' mathematical perception can be determined by mental structure or frame of mind established by them within themselves. Therefore, building mathematics experiences requires problem negotiation and mathematical situations encountered in their environment (Battista, 2010).

Some models and concepts of mathematics were found; including the algebra concept, namely the comparison in which the size of a house to be built is adjusted to the number of families that will reside in. In addition, modulo mathematics was the mathematical found in the study. The form of this modulo calculation was found to determine the residential character of the house to be built, and the concept of arithmetic progression was also found in determining the residential character if sikut awak or standard house heights are not used. Consistent with the study by Utami et al. (2019) regarding Javanese primbon that observed numerical values 
using ethnomathematics. The mentioned study found that the calculation of Javanese Primbon uses a mathematical concept, i.e., modulo arithmetic.

Ethnomathematics is perceived as discovering mathematical ideas that exist in a culture. Principles of ethnomathematics do not offer a static learning experience. Instead, they provide a framework where students can consistently connect the experience they find in the environment with new knowledge acquired in class (D'Ambrosio \& D'Ambrusio, 2013). Mathematics will still be personally relevant to students when this approach is carried out. The way to solve complicated problems is began from the current challenges faced by students as the outcome of their socio-cultural experiences and later developed based on the interest of students and their freshly-acquired experience (D'Ambrosio, 2001). An approach involving the socio-cultural aspect emphasizes the learning and problem solving relevant to the environment encountered by students or the outcome of the interaction between students and the environment as new knowledge (Brough \& Calder, 2014).

\section{Conclusion}

In determining the residential character or feature based on sikut awak, Sasak people use mathematical calculation. There are ten characters or natures of residence that being used. Based on the calculation done by belian bale, not all of these characters are good for the residents. Sikut awak is the owner's depa length based on the measurement done by belian bale that is used in determining the residential character or feature of the house to be built. However, the owner's depa length is not entirely representative of the height of the building to be built. In that order, belian bale uses the standard house height of Sasak people. A ritual orientation or customary procession is found in a residence that is closely related to cultural and religious functions. In that order, different orientations and habits will make humans produce different cultures. In its mathematical calculation, measurement and comparison concepts and series and progression concepts are used to determine residential characters in general.

The finding of characters or features of a residence to be built uses arithmetic modeling that integrates modulo 10. Much belian bale still uses this kind of calculation concept, especially in traditional villages preserved in Lombok Island. This study indicates that cultural activities containing mathematics modeling can be made as the initial step in learning mathematics, especially in numbers and modulo. The results of this study can also be made as the reference for teachers in Lombok Island to improve students' learning motivation by integrating their cultures. 


\section{Conflicts of Interest}

The authors declare that no conflict of interest regarding the publication of this manuscript. In addition, the ethical issues, including plagiarism, misconduct, data fabrication and/or falsification, double publication and/or submission, and redundancies have been completely by the authors.

\section{References}

Alkhusairi. (2016). Pengembangan model pembelajaran matematika berbasis budaya Sasak [Development of a Sasak culture-based mathematics learning model] [Unpublished Doctoral Dissertation]. Universitas Negeri Yogyakarta.

Anglin, W. S. (1994). Mathematics: A concise history and pholosophy. Springer Verlag. https://doi.org/10.1007/978-1-4612-0875-4

Ascher, M., \& D'Ambrosio, U. (2012). Ethnomathematics : a Dialogue. For the Learning of Mathematics, 14(2), 36-43.

Battista, M. T. (2011). Engaging students in meaningful mathematics learning: Different perspectives, complementary goals. Journal of Urban Mathematics Education, 3(2), 3446.

Brough, C., \& Calder, N. (2014). Making mathematics meaningful: Using studentinitiated problems to situate mathematics. Australian Primary Mathematics Classroom, 19(1), 913. https://doi.org/10.1109/FIE.2008.4720673

Burton, M. (2010). Five trategies for creating meaningful mathematics experiences in the primary years. Young Children, 65(6), 92-96.

Ching, F. D. K. (2017). Architecture: Form, space and order (3 nd). John Wiley \& Sons, Inc.

D'Ambrosio, U., \& D'Ambrosio, B. S. (2013). The role of ethnomathematics in curricular leadership in mathematics education. Journal of Mathematics Education at Teachers College, 4, 19-25.

D’Ambrosio, U. (2007). Ethnomathematics: Perspectives. NASGEM News, 2(1), 2-3. https://citeseerx.ist.psu.edu/viewdoc/download?doi=10.1.1.417.9195\&rep=rep1\&type= pdf

D'Ambrosio, U. (2001). What is ethnomathematics, and how can it help children in schools? Teaching Children Mathematics, 7(6), 308-310. https://doi.org/10.5951/TCM.7.6.0308

D'Ambrosio, U. (2016). State of the art in ethnomathematics. In Milton Rosa, U. D'Ambrosio, D. C. Orey, L. Shirley, W. V. Alangui, P. Palhares, \& M. E. Gavarrete (Eds.), Current and Future Perspectives of Ethnomathematics as A Program (pp. 11-37). Camp. Springer US.

Ernest, P. (1991). The philosophy of mathematics education. Falmer Press.

Fatrurrahman, L. A. (2016). Membaca arsitektur Sasak [Reading Sasak architecture]. Genius.

Freudenthal, H. (2002). Revisiting mathematics education. Springer Netherlands. https://doi.org/10.1007/0-306-47202-3

Ghaffarianhoseini, A., Berardi, U., Dahlan, N. D., \& Ghaffarianhoseini, A. (2014). What can we learn from Malay vernacular houses? Sustainable Cities and Society, 13, 157-170. https://doi.org/10.1016/j.scs.2014.04.008

Kimberly Mah. (2013). Architecture and the human behaviour. 1-44. http://library1.nida.ac.th/termpaper6/sd/2554/19755.pdf

Kirchgräber, U. (2001). The teaching and learning of mathematics at university level. In M. Artigue, U. Kirchgräber, J. Hillel, M. Niss, A. Schoenfeld, \& (Section Editors) (Eds.), Changing contexts in tertiary mathematics: Implications for diversity and equity (pp. 13- 
26).

Markevičiene, J. (2012). The spirit of the place - the problem of (re) creating. Journal of $\begin{array}{llll}\text { Architecture } \quad \text { Und } & \text { 36(1), }\end{array}$ https://doi.org/10.3846/20297955.2012.679789

Prahmana, R. C. I., Yunianto, W., Rosa, M., \& Orey, D. C. (2021). Ethnomathematics : Pranatamangsa system and the birth-death ceremonial in Yogyakarta. Journal on Mathematics Education, 12(1), 93-112. https://doi.org/10.22342/jme.12.1.11745.93-112

Ruff, C. L., \& Olson, M. A. (2009). The attitudes of interior design students towards sustainability. Int J Technol Des Educ, 19(1), 67-77. https://doi.org/10.1007/s10798-007$\underline{9038-0}$

Sabilirrosad. (2014). Etnomatematika tenun Sasak [Ethnomathematics of Sasak weaving] [Unpublished Master Thesis]. Universitas Negeri Yogyakarta.

Spradley, J. P. (2016). The ethnographic interview. In The SAGE Encyclopedia of Communication Research Methods. Reissued Long Grove, IL: Waveland Press, Inc. https://doi.org/10.4135/9781483381411.n168

Supiyati, S. (2019). Nilai-nilai budaya Sasak dalam perspektif etnomatematika [Sasak cultural values in ethnomathematics perspective] [Unpublished Doctoral Dissertation]. Universitas Negeri Yogyakarta.

Utami, N. W., Sayuti, S. A., \& Jailani. (2019). Math and mate in Javanese Primbon: Ethnomathematics study. Journal on Mathematics Education, 10(3), 341-356. https://doi.org/10.22342/jme.10.3.7611.341-356

Zhang, D. (2019). Traditional dwellings interrogating. Journal of The International Association for The Study of Traditional Environments, XX(1), 15-36. 